\title{
Regulatory Aspects of ATMP Versus Minimally Manipulated Immune Cells
}

\author{
Eoin McGrath and Christian Chabannon
}

Under current European regulations, hematopoietic cellular therapies fall under two categories: stem cell transplants and advanced therapy medicinal products (ATMPs). Routinely administered auto- and allo-HSCT-including subsequent peripheral blood allogeneic mononuclear cells (DLI) - undergo non-substantial manipulations following cell procurement and before being administered to the recipient.

Cell processing is performed in facilities termed tissue establishments (TEs) under the EU Tissues and Cells Directive (see https://ec.europa. eu/health/blood_tissues_organs/tissues_en. Accessed 20 Feb 2018), and these are authorized by national and/or regional competent authorities (CA). TEs usually operate on a relatively small scale, serving the clinical program(s) in their immediate vicinity although some national or regional services may support a more extensive network of clinical programs. The combination of a clinical department(s) with a collection and a processing facility represents the core structure

\footnotetext{
E. McGrath

European Society for Blood and Marrow

Transplantation (EBMT), Barcelona, Spain

C. Chabannon $(\bowtie)$

Institut Paoli-Calmettes, Centre de Lutte Contre le Cancer, Marseille, France

Université d'Aix-Marseille, Marseille, France

Inserm BCT-1409, Centre d'Investigations Cliniques en Biothérapies, Marseille, France

e-mail: chabannonc@ipc.unicancer.fr
}

for a transplant program that applies for the JACIE accreditation (see Chap. 5). Such an organization leaves room for significant procedural and organizational variations, many driven by local or national factors, despite all attempts from the various professional associations to harmonize practices through surveys, the publication of guidelines, and regularly revised standards for these therapies, e.g., FACT-JACIE International Standards for Hematopoietic Cellular Therapies (see www.jacie.org. Accessed 19 Feb 2018).

ATMPs represent a new category of medicinal products defined in EU Regulation 1394/2007 (see http://eur-lex.europa.eu/LexUriServ/ LexUriServ.do?uri=OJ:L:2007:324:0121:0137:e n:PDF. Accessed 20 Feb 2018). ATMPs—known in the USA as human cells, tissues, and cellularand tissue-based products (HCT/Ps) regulated under Section 351 of the PHS Act and/or the FD\&C Act (see https://www.fda.gov/biologicsbloodvaccines/tissuetissueproducts/regulationoftissues/ucm150485.htm. Accessed 21 Feb 2018) - are subdivided in four categories, of which two are relevant in the context of hematopoietic cellular therapies: somatic cell therapy medicinal products (SCTMP) and gene therapy medicinal products (GTMP). Examples of SCTMP include ex vivo expanded autologous or allogeneic stem cells (de Lima et al. 2012; Delaney et al. 2010), mesenchymal stem cells (Le Blanc et al. 2008), and allogeneic T lymphocytes depleted of alloreactive $\mathrm{T}$ cells (AndreSchmutz et al. 2002). Examples of GTMP 
include allogeneic $\mathrm{T}$ cells engineered to express a suicide gene (Ciceri et al. 2009), autologous or allogeneic CAR-T cells (Schuster et al. 2017; Neelapu et al. 2017), and autologous CD34+ cells genetically engineered to express a miniglobin gene and designed to treat inherited $\beta$-globin disorders (Cavazzana-Calvo et al. 2010; Ribeil et al. 2017).

The regulation was designed in part to foster the competitiveness of European pharmaceutical companies in this emerging field, but the number of ATMPs that have received a centralized marketing authorization remains relatively low and with poor overall commercial success so far. In the HSCT field, it was not until 2015 that an ATMP of interest reached the market with authorization given for Zalmoxis ${ }^{\circledR}$ (allogeneic T cells engineered to express a suicide gene). Production, distribution, and administration of ATMPs imply a totally different organization than that used for HSCT, with manufacturing at a central facility in compliance with good manufacturing practices (GMP) (Wang and Rivière 2016, 2017), a version of which was recently released by the European Medicines Agency (EMA) to specifically deal with manufacturing of ATMPs (see https:// ec.europa.eu/health/sites/health/files/files/ eudralex/vol-4/2017_11_22_guidelines_gmp_ for_atmps.pdf. Accessed 19 Feb 2018). Since a majority of the ATMPs that progress to authorization or at least to clinical trials are manufactured from autologous mononuclear cells, starting material is currently procured by hospital- or blood bank-operated apheresis facilities creating a peculiar situation in which a product starts under one regulation-Tissues and Cells Directive-before passing to another, ATMP Regulation, and where a hospital acts as a service provider to industry, an interaction that requires further definition of the respective responsibilities and liabilities.

Publication of Regulation 1394/2007 created a situation in which some cell- or tissue-based therapeutic products that were previously prepared and delivered through an organization similar to that for cell transplants were classified as ATMPs. This had a limited impact in the field of hematopoietic cellular therapies, although some cell-based products such as allogeneic $\mathrm{T}$ cells with specific anti-CMV activity engineered through the gamma-catch technology (Feuchtinger et al. 2010) were affected. In recognizing that many potential ATMP were used for limited numbers of patients and with no commercial motivation, Regulation 1394/2007 created the so-called hospital exemption (HE) under Article 28 exempting from authorization requirements those ATMPs manufactured in hospitals, universities, or start-up companies where the medicine is prescribed for individual patients under the care of a medical practitioner. This manufacture should occur on a non-routine basis according to specific quality standards (GMP) (Vives et al. 2015), and the ATMP should be used in a hospital and only within the same member state. National authorities oversee the approval of HE products which has resulted in significant variations between member states in how it is applied and which has led to criticism from both industry and academia that it is unclear and inconsistent.

Access to ATMPs including cellular therapies is likely to be a particular challenge for patients, healthcare professionals, and national health systems due to their expected high costs. Even access to decades-old HSCT remains strongly associated with higher-income countries (Gratwohl et al. 2015). One potential effect of limited access could be the so-called stem cell tourism whereby patients with the means travel to centers outside their own countries for care and who may be vulnerable to false promises or may not have access to all of the information needed to make this important decision. The International Society for Cellular Therapy (ISCT) leads the publication of patient advice and other documentation on this phenomenon (see http://www.celltherapysociety.org/page/ UCT. Accessed 21 Feb 2018).

Academic facilities including stem cell transplant practitioners at large should strive to remain active players in the development of ATMPs. Academia remains very active in the early phases of clinical trials designed to evaluate innovative SCTMP and GTMP as potential complements, substitutes, or bridges to historical forms of 
hematopoietic cell transplants (Pearce et al. 2014). One recent study calculated that only $20 \%$ of CAR T cell trials are sponsored by pharmaceutical industry (Hartmann et al. 2017). Many public institutions have invested significant resources to upgrade their processing facilities to GMPcompliant levels thus allowing for small-scale manufacturing of experimental medicinal products to support phase I and possibly phase II studies, often with the hope that industry will take over in case that promising results warrant further development (de Wilde et al. 2016a). Furthermore, academia has to become a proactive stakeholder in the regulatory area by engaging with the authorities, sharing their know-how, and voicing their opinion (de Wilde et al. 2016b).

The field is moving at a fast pace. So far, there has been proof of concept that tissue-based or cell-based medicinal products can be manufactured by a "conventional" pharmaceutical company (Locke et al. 2017), although with continued reliance on critical contributions from academic facilities, e.g., basic science and provision of starting materials. Some of these innovative medicinal products have remarkable clinical efficacy for severe or debilitating diseases although sometimes at the expense of equally remarkable toxicity. However, a commercial ATMP "hit" is still to emerge which could explain why the CAR-T cell field is being highly scrutinized by clinicians, regulators, and industry after the first two marketing authorizations for CAR-T cell therapies were granted by FDA in the USA in 2017 and by EMA in the EU in August 2018. These developments carry many regulatory and operational uncertainties including the very sustainability of how academic facilities currently deliver HSCT, but availability of this new category of innovative medicinal products offers new hopes to patients. Their therapeutic pathway is likely to become increasingly complex (Chabannon et al. 2015) and will require longterm follow-up for evidence of sustained clinical efficacy and detection of late adverse effects (see http://www.ema.europa.eu/ema/index.jsp?curl=p ages $\% 2$ Fregulation $\% 2$ Fgeneral $\% 2$ Fgeneral_ content_000658.js p \& mid=W C 0 b 0 1ac0580961211). Academia through continental registries such as EBMT will continue to play a key role with data and know-how that will be very useful not just for researchers but also for industry, healthcare regulators, and payers.

\section{Key Points}

- In this chapter, we review the fastevolving regulatory framework that leads to the coexistence of two categories of hematopoietic cell-based therapeutics.

- Innovative and industry-manufactured somatic cell therapy or gene therapy medicinal products are now entering the field at an accelerating pace and will complete or compete with traditional HSCT practices in the near future.

- We describe the organizational consequences for academic facilities of this historical shift that brings new opportunities to patients and practitioners in the field.

\section{References}

Andre-Schmutz I, Le Deist F, Hacein-Bey-Abina S, et al. Immune reconstitution without graft-versus-host disease after haemopoietic stem-cell transplantation: a phase 1/2 study. Lancet. 2002;360:130-7.

Cavazzana-Calvo M, Payen E, Negre O, Wang G, Hehir $\mathrm{K}$, Fusil F, et al. Transfusion independence and HMGA2 activation after gene therapy of human betathalassaemia. Nature. 2010;467:318-22.

Chabannon C, Hildebrandt M, Scheding S, Humpe A, Lowdell M, Slaper-Cortenbach I. Regulation of advanced therapy medicinal products will affect the practice of haematopoietic SCT in the near future: a perspective from the EBMT cell-processing committee. Bone Marrow Transplant. 2015;50:321-3.

Ciceri F, Bonini C, Stanghellini MT, Bondanza A, Traversari C, Salomoni M, et al. Infusion of suicidegene-engineered donor lymphocytes after family haploidentical haemopoietic stem-cell transplantation for leukaemia (the TK007 trial): a non-randomised phase I-II study. Lancet Oncol. 2009;10:489-500.

de Lima M, McNiece I, Robinson SN, et al. Cord-blood engraftment with ex vivo mesenchymal-cell coculture. N Engl J Med. 2012;367:2305-15.

de Wilde S, Guchelaar HJ, Herberts C, Lowdell M, Hildebrandt M, Zandvliet M, et al. Development of cell therapy medicinal products by academic institutes. Drug Discov Today. 2016a;21:1206-12. 
de Wilde S, Veltrop-Duits L, Hoozemans-Strik M, Ras T, Blom-Veenman J, Guchelaar HJ, et al. Hurdles in clinical implementation of academic advanced therapy medicinal products: a national evaluation. Cytotherapy. 2016b;18:797-805.

Delaney C, Heimfeld S, Brashem-Stein C, et al. Notchmediated expansion of human cord blood progenitor cells capable of rapid myeloid reconstitution. Nat Med. 2010;16:232-6.

Feuchtinger T, Opherk K, Bethge WA, et al. Adoptive transfer of pp65-specific T cells for the treatment of chemorefractory cytomegalovirus disease or reactivation after haploidentical and matched unrelated stem cell transplantation. Blood. 2010;116:4360-7.

Gratwohl A, Pasquini MC, Aljurf M, et al. One million haemopoietic stem-cell transplants: a retrospective observational study. Lancet Haematol. 2015;2:e91-100.

Hartmann J, Schussler-Lenz M, Bondanza A, Buchholz CJ. Clinical development of CAR T cells-challenges and opportunities in translating innovative treatment concepts. EMBO Mol Med. 2017;9:1183-97.

Le Blanc K, Frassoni F, Ball L, et al. Mesenchymal stem cells for treatment of steroid-resistant, severe, acute graft-versus-host disease: a phase II study. Lancet. 2008;371:1579-86.

Locke FL, Neelapu SS, Bartlett NL, et al. Phase 1 results of ZUMA-1: a multicenter study of KTE-C19 anti-
CD19 CAR T cell therapy in refractory aggressive lymphoma. Mol Ther. 2017;25:285-95.

Neelapu SS, Locke FL, Bartlett NL, et al. Axicabtagene ciloleucel CAR T-cell therapy in refractory large B-cell lymphoma. N Engl J Med. 2017;377:2531-44.

Pearce KF, Hildebrandt M, Greinix H, Scheding S, Koehl $\mathrm{U}$, Worel N, et al. Regulation of advanced therapy medicinal products in Europe and the role of academia. Cytotherapy. 2014;16:289-97.

Ribeil JA, Hacein-Bey-Abina S, Payen E, et al. Gene therapy in a patient with sickle cell disease. N Engl J Med. 2017;376:848-55.

Schuster SJ, Svoboda J, Chong EA, Nasta SD, Mato $\mathrm{AR}$, Anak $\mathrm{O}$, et al. Chimeric antigen receptor $\mathrm{T}$ cells in refractory B-cell lymphomas. N Engl J Med. 2017;377:2545-54.

Vives J, Oliver-Vila I, Pla A. Quality compliance in the shift from cell transplantation to cell therapy in nonpharma environments. Cytotherapy. 2015;17:1009-14.

Wang X, Rivière I. Clinical manufacturing of CAR T cells: foundation of a promising therapy. Mol Ther Oncolytics. 2016;3:16015. https://doi.org/10.1038/ mto.2016.15.

Wang X, Riviere I. Genetic engineering and manufacturing of hematopoietic stem cells. Mol Ther Methods Clin Dev. 2017;5:96-105.

Open Access This chapter is licensed under the terms of the Creative Commons Attribution 4.0 International License (http://creativecommons.org/licenses/by/4.0/), which permits use, sharing, adaptation, distribution and reproduction in any medium or format, as long as you give appropriate credit to the original author(s) and the source, provide a link to the Creative Commons license and indicate if changes were made.

The images or other third party material in this chapter are included in the chapter's Creative Commons license, unless indicated otherwise in a credit line to the material. If material is not included in the chapter's Creative Commons license and your intended use is not permitted by statutory regulation or exceeds the permitted use, you will need to obtain permission directly from the copyright holder.

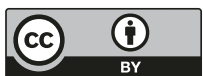

